\title{
L'énergie solaire dans les campagnes indiennes
}

Le programme Asvin du CNRS

\section{Denis Blamont}

\section{(2) OpenEdition}

Journals

Édition électronique

URL : https://journals.openedition.org/tc/777

DOI : $10.4000 /$ tc. 777

ISSN : 1952-420X

Éditeur

Éditions de l'EHESS

\section{Édition imprimée}

Date de publication : 1 octobre 1990

ISSN : 0248-6016

\section{Référence électronique}

Denis Blamont, «L'énergie solaire dans les campagnes indiennes », Techniques \& Culture [En ligne], 14 | 1990, mis en ligne le 16 janvier 2006, consulté le 29 septembre 2022. URL : http://

journals.openedition.org/tc/777 ; DOI : https://doi.org/10.4000/tc.777

Ce document a été généré automatiquement le 29 septembre 2022.

Tous droits réservés 
L'énergie solaire dans les campagnes indiennes

Le programme Asvin du CNRS

Denis Blamont 